\title{
ВІКОВІ ЗАКОНОМІРНОСТІ РОЗВИТКУ ТВОРЧОЇ СОЦІАЛІЗАЦІЇ ЮНАКІВ
}

Статтю присвячено теоретичному аналізу вікових закономірностей розвитку творчої соиіалізаиії юнаків. Здійснено аналіз наукової літератури, що розкриває зміст поняття «творча соиіалізація». Обтрунтовано основні складові творчої сочіалізаиї юнаків: сочіально-психологічна адаптаиія, фрустраиія, соиіальний статус, соиіальне визнання, набуті характеристики, образне $i$ вербальне творче мислення, оригінальність тематична. Встановлено суть творчої соиіалізації юнаків. 3'ясовано, щзо зміст і структура творчої сочіалізачії юнаків базуються на їх вікових особливостях $i$ взаємозв 'язку складових сочіалізаџї і творчого мислення. Обгрунтовано, що творча сочіалізація юнаків є процесом стійкої, загальної адаптованості і проявляється у майстерності, винахідливості, соиіальній лабільності, в якій здійснюється їх творче самовизначення.

Ключові слова: сочіалізація, соціально-психологічна адаптаџія, сочіальний статус, соціальне визнання, набуті характеристики, образне і вербальне творче мислення, фрустрачія, орихінальність тематична, сочіальна творчість, творча адаптація, творча соиіалізація юнаків, складові творчої соиіалізаиіï.

Статья посвящена теоретическому анализу возрастных закономерностей развития творческой социализаџии юношей. Осуществлен анализ научной литературы, раскрывает содержсание понятия «творческая социализация». Обоснованы основные составляющие творческой сочиализаџии юномей: социально-психологическая адаптаџия, фрустрация, сочиальныий статус, сочиальное признание, приобретенные характеристики, образное и вербальное творческое мыпиление, оригинальность тематическая. Установлено суть творческой сочиализации юночей. Определено, что содержание и структура творческой социализации юношей базируются на их возрастных особенностях и взаимосвязи составляющих сочиализачии и творческого мышления. Обосновано, что творческая социализачия юношей является прочессом устойчивой, общей адаптированности и проявляется в мастерстве, изобретательности, соииальной лабильности, $в$ которой осуществляется их творческое самоопределение.

Ключевые слова: сочиализация, сочиально-психологическая адаптащия, соииальный статус, социальное признание, приобретенные характеристики, образное и вербальное творческое мылиление, фрустрация, оригинальность тематическая, социальное творчество, творческая адаптаџия, творческая сочиилизация юношей, составляющие творческой сочииализаџии.

Постановка проблеми. Творча соціалізація щодня присутня у житті людини у контакті 3 собою і з іншими. Це процес постійного розвитку і творення себе і свого середовища на рівні суб'єктивних переживань, роздумів і у взаємодії з суспільством. Цей процес є різноманітним і має свою динаміку і статику щодо віку, результатів успіху, продуктів діяльності тощо. Вікові закономірності юнаків мають ряд базових передумов для розвитку їх творчої соціалізації. Це період відкриттів і досліджень своїх здібностей, обдарувань, талантів, період дорослішання і побудови професійного самовизначення. Саме у юнацькому віці важливо здійснити вирішальний старт у доросле, відповідальне життя, бути одночасно ризикованим, поміркованим і творчо адаптованим в постійно мінливому соціальному просторі.

Аналіз останніх досліджень і публікацій. У соціально-психологічній літературі можна зустріти різні погляди на процес соціалізації, який може мати дві сторони (пасивну і активну). Пасивна сторона передбачає пристосування індивіда до середовища, до життя як до вже поставленої 
суспільством задачі, тобто підпорядкування під уже наявні умови; активна сторона передбачає творчу активну зміну середовища, прояв перетворювально-творчої поведінки із ставленням до життя як до творчої задачі і підпорядкування оточення своїм потребам (Г. Алдер, Г.О.Балл, Г. С. Батищев, Н. Ф. Голованова, В. М. Дружинін, О. Г. Карпенко, Л. С. Смолінчук, В. Т. Циба, В. С. Юркевич) [1; 2; 9]. Іншу важливу особливість взаємозв'язку двох процесів - соціалізації і творчості - в науковій літературі представлено у таких поняттях як «соиіальна творчість», «соиіальна креативність», «соиіальна обдарованість», що є вищою формою соціальної активності особистості або суспільства, специфічним видом творчості і виражається у здатності індивіда до генералізації ідей у площині соціальної проблематики, в процесі різноманітних соціальних взаємодій, у спроможності особи здійснювати суттєві перетворення в об'єкті активності (його моделі) з метою їх активного пізнання та реструктуралізації (Т. Н. Балабанова, О. І. Власова， Л. Б. Срмолаєва-Томіна, Е. Ландау, О. І. Ніколаєва, О. І. Кульчицька, Л. В. Попова, Р. О. Семенова, О. Ю. Тургенєва) [3; 12].

Науковий аналіз розкриває також взаємозв'язок процесів соціалізації і творчого мислення, який відображається в поняттях «творча адаптаиія», «життєтворча адаптованість». Сутність процесу творчої адаптациї полягає у самозмінах і змінах, перебудовах соціальних ситуацій на підставі незахисних адаптивних механізмів та створення умов для нової цілеспрямованої, продуктивної, творчої діяльності, яка приймається і позитивно оцінюється соціумом; тобто нова швидка й оригінальна адаптація до швидкоплинного навколишнього світу (А. А. Налчаджян, К. Роджерс, В. М. Ямницький) $[12 ; 14]$.

Аналіз новітніх досліджень взаємозв'язку двох процесів: соціалізації і творчого мислення дозволив виокремити поняття «творчої соціалізації», яке недавно з'явилося у вітчизняних (О. А. Туріна) і зарубіжних (Л. В. Коломийченко) дослідженнях. Суть процесу творчої соиіалізаиії виражається у найвищому щаблі соціалізації людини в середовищі - активне входження особи у світ суспільства шляхом творчо-перетворюючої дії задля позитивної зміни в процесі освоєння традицій, норм і цінностей культури [5; 13].

Формулювання цілей статті. Здійснити теоретичний аналіз вікових закономірностей розвитку творчої соціалізації юнаків.

Виклад основного матеріалу дослідження. Старший шкільний вік або ранню юність (15-17 років) вважають третім світом, що існує між дитинством та дорослістю. У цей час юнак опиняється на порозі реального дорослого життя і дивиться на теперішне з позиції майбутнього, шукає смисл свого життя [12]. Численні задачі, що за цей час необхідно вирішити для розвитку повноцінної особистості, можна звести до двох основних проблем - формування соціальної зрілості (під досягненням соціальної зрілості потрібно розуміти, з одного боку, можливість виконання соціальних обов'язків, з іншого боку - прийняття відповідальності за власне життя, рішення і вчинки на самого себе) і самосвідомості. Тому у ранній юності, на основі прагнення старшокласників до автономії, формується повна структура самосвідомості, яка дозволяє їм оцінювати свої здібності, особистісні якості та займатися самовдосконаленням; посилення інтересу до своєї особистості є умовою цілеспрямованої самоосвіти та самовиховання [10].

У юності провідним центром всього розвитку стає особистісне самовизначення, потребу в самовизначенні складає вибір життєвого шляху, життєвих планів. Самовизначення у юнацькому віці означає не автономію від дорослих, а чітку орієнтацію та визначення свого місця у дорослому світі (Л. І. Божович, Л. С. Славіна, Е. Еріксон), зазначає О. В. Скрипченко. Провідною на цьому етапі стає навчально-професійна діяльність [12]. Так, за культурно-історичною концепцією соиіалізації Л. С. Виготський фіксує, що навчальна діяльність для старшокласника $є$ засобом реалізації життєвих планів на майбутнє. Саме у старшому шкільному віці проявляється свідоме позитивне ставлення до навчання, яке спрямоване на організацію, комплектування, систематизацію індивідуального досвіду за рахунок розширення, доповнення, внесення пової інформації, розвитку самостійності, творчого підходу до рішень, тощо. У зв'язку з цим Ю. М. Швалб вказує на цілепокладання як важливий компонент особистісного розвитку старшокласників у процесі соціалізації.

Поряд 3 навчанням провідною діяльністю виступає особлива діяльність по встановленню інтимно-особистісних відносин, названа діяльністю спілкування, всередині якої формуються спільні погляди на життя, на майбутнє, тобто особистісне самовизначення, самосвідомість як «соціальна свідомість, перенесена всередину» (Т. В. Драгунова, Б. Д. Ельконін) [12].

Успішна соціалізація старшокласників залежить і від їхнього соціального статусу в групі. Так, дослідження С. Д. Максименка і Т. Д. Щербана [2; 4] показали, що однією з найефективніших для психічного, передусім розумового, розвитку школярів, зокрема старшокласників, $є$ така форма організації спільної діяльності, при якій соціометричний статус всіх учнів класу однорідний і рівень

Випуск 11, 2018. Збірник наукових праць РДГУ 
успішності учнів класу відносно однорідний. Надзвичайно важливою є потреба не просто входити до складу групи, а бути прийнятим однолітками, відчувати свою необхідність, мати у групі певний авторитет. Низький статус у групі, як правило, корелює з високим рівнем особистісної тривожності. Вибірково-оцінне ставлення учнів старших класів до свого оточення знаходить прояв у референтній групі, престижі, авторитеті, популярності, підкреслює О. З. Лютак [12]. У свою чергу, високі вимоги, які ставить до себе творчий юнак, стають бар'єром для налагодження дружніх стосунків iз ровесниками, зазначає О. Д. Музика [7]. Збагнувши відмінності від інших за рівнем здібностей, творчі юнаки свідомо досягають такого статусу, який давав би їм можливість здійснювати незалежну творчу працю у потрібному темпі та напрямі. 3 цього випливає, що до складових соціалізації старшокласників потрібно віднести соиіальне визнання і соиіальний статус.

В контексті інтегральної концепиії соціалізації особистості модель А. В. Петровського змістовно відображає процес соціалізації учнів старшого шкільного віку за трьома фазами: адаптацією, індивідуалізацією і інтеграцією. Виходячи з цього, О. З. Лютак дослідив, що соціалізація є суб'єктивним процесом і джерелом індивідуалізації, тому що кожен учень 3 об'єктивно однакових ситуацій виносить різний соціальний досвід і саме в процесі соціалізації та соціальної адаптації складним і суперечливим шляхом набуває своєї індивідуальності [12].

У процесі соціалізації юнаки стають членами суспільства 3 конкретними соціальнополітичними, соціально-економічними та культурними параметрами. Під впливом соціалізації формується орієнтація старшокласників на певну ціннісно-нормативну систему, тому засвоєння старшокласником соціальних цінностей та норм $\epsilon$ рушійною силою його здатності творчо адаптуватися до нових соціальних умов і згодом творити ці умови (креативний аспект). Цей факт підкреслює наступну складову соціалізації старшокласників, яка характеризується як соціальна адаптаиія.

У своїх дослідженнях О. О. Реан [9] стверджує, що пізнавальні процеси старшокласників набувають таких якостей, які роблять їх більш досконалими і гнучкими, причому розвиток особливостей пізнання дуже часто випереджає власне особистісний розвиток юнат. Хоча дослідження М. Л. Смульсон доводять, що не до кінця можна погодитися з такими висновками, виходячи 3 розвитку регулятивної системи старшокласника, яка може призводити до контрадаптивної, дезадаптивної поведінки, або десоціалізації, яка виникає у зв'язку 3 неузгодженістю між мотивами і діями, вербальним та реальним планом, намірами та результатами дій, неадекватністю установки особистості й об'єктивних актуальних вимог ситуації та ін. Слід також пам'ятати про можливі загострення типових рис акцентуацій характеру, зокрема гіпертимність; своєрідна вікова інтровертованість; яскраво виражена статеворольова диференціація може межувати 3 досить частою інфантильно-рольовою негнучкістю; відчуттям самотності; негативною ідентичністю, тощо. Проте, на противагу вище наведеним аспектам, зауважуємо, що у старшокласників свідомо і цілеспрямовано формуються такі якості характеру, як сила волі, витримка, наполегливість, самоконтроль, обдуманість, критичність, допитливість, ризикованість тощо. Тому знижується гострота міжособистісних конфліктів, менше проявляється негативізм у ставленні до оточуючих, покращується фізичне й емоційне самопочуття, підвищується комунікабельність, знижується рівень тривожності, нормалізується самооцінка [8].

Ці факти обумовлюють складові соціалізації старшокласників, які характеризуються помірним проявом фрустраціï і формуванням нових рис характеру. На думку Г. С. Костюка, важливим аспектом психічного розвитку людини в старшому шкільному віці $\epsilon$ інтенсивне інтелектуальне дозрівання, зокрема, нестандартний підхід до вже відомих проблем, вміння включати часткові проблеми у більш загальні тощо. Таким чином, старшокласники переходять до вищих рівнів абстрагуючого та узагальнюючого мислення, тобто проявляється яскраво виражена схильність до теоретизування, творення абстрактних теорій, захоплення філософськими міркуваннями, розвиток творчої уяви у різноманітних видах творчої діяльності (М. С. Лейтес, Ж. П'яже) [12]. В. А. Роменець змістовно досліджував розвиток уяви, творчого мислення і творчості у старшому шкільному віці, акцентуючи увагу на тому, що сучасні юнаки активно використовують буденні речі для прояву власного творчого мислення в різноманітній юнацькій літературній творчості, де живо і яскраво зображують переживання інших людей, подають курйозні незвичайні образи, удавано-оригінальні, максималістичні, ідеалізовані образи, виявляючи таким чином власні творчі індивідуальні здібності [10]. Завдяки цьому процес міркування стає економнішим, продуктивнішим; формується система взаємопов'язаних узагальнених і образних операцій.

За О. І. Василец, Л. Г. Подоляк, О. О. Реаном, Ю. С. Симоном, Т. Томе [1; 4; 7-12] старший шкільний вік характеризується посиленням індивідуалізації. Так, значна частина юнаків цього віку характеризується відсутністю інтересу до пізнавальної діяльності, їм притаманна розкиданість, 
відсутність систематизованості поглядів і підходів, адекватної оцінки своїх можливостей, схильність перебільшувати рівень своїх знань, особливо розумових можливостей. Інших юнаки байдуже відносяться до рутинного, монотонного навчання, що не дає простору їх індивідуальним творчим здібностям і ініціативі. Юнакам властивий так званий прагматичний тип розвитку особистості, що характеризується орієнтацією юнака на доцільність і на уникнення від джерел неспокою. У юнаків такого типу домінують матеріальні цінності та інтереси. Для них важливе прагнення до гомеостатичної рівноваги, уникнення будь-яких проблем. I це перешкоджає їх подальшому індивідуальному розвиткові. Вони не прагнуть до одержання вищої освіти. Відбувається прояв нормативного аспекту соиіалізащії, що означає інтеріоризацію старшокласником соціальних норм у незмінному вигляді. Інші юнаки виявляють справжню цікавість до навчання i творчості. Тому що розвиток інтелекту у старшокласників на даному етапі тісно пов’язаний з розвитком творчих здібностей, що означає не просте засвоєння інформації, а прояв інтелектуальної ініціативи і створення чогось нового. До них належать юнаки творчо-оріснтованого типу розвитку особистості, що характеризуються прагненнями та інтересами, спрямованими в майбутнє. Вони активно включають у власний спосіб життя різні пізнавальні та інші можливості. Відбувається прояв креативного аспекту соиіалізаиії, що означає видозміну соціальних норм у процесі засвоєння, «інтериоризовані норми не сприймаються старшокласником як примусові, вони зливаються в одне ціле 3 його правилами та нормами і виступають внутрішніми регуляторами поведінки, утворюючи іiі установку». Так, за дослідженнями М. Парлофа і Л. Датта [1] - юність психологічно більш рухлива і схильна до захоплень. У той же час, щоб стати творчо продуктивним, юнак має потребу в більшій інтелектуальній дисципліні і зібраності, відрізняючись цим від своїх імпульсивних однолітків.

У своїх дослідженнях В. М. Дружинін [2] виявив, що на підлітковий і ранній юнацький вік (від 13 до 20 років) припадає формування «спеціалізованої» креативності: здатність до творчості, пов'язаної з певною сферою людської діяльності. На цьому етапі особливо значиму роль грає професійний зразок, підтримка родини й однолітків. Але головне, юнак визначає для себе «ідеальний зразок» творця, якого він прагне наслідувати (аж до ототожнення). Індивід або затримується на фазі наслідування назавжди, або переходить до оригінальної творчості.

Вікову періодизацію творчої діяльності запропонував український психолог В. О. Моляко [6], виділяючи підлітковий і юнацький вік як другий етап творчої діяльності, яка характеризується конструюванням свого уявлення про світ, літературною і технічною творчістю. Дослідження Н. І. Гайдамашко показали, що здатність креативного вирішення «технічних» проблем може бути повністю блокована «соціальними» факторами у групі дорослих, і в той же час, при вирішенні тих же проблем підлітки і старшокласники не бачать зовсім ніяких труднощів. Очевидно, що в даному випадку мова може йти саме про різні механізми розвитку креативності залежно від того типу соціальних відношень, в які включений суб'єкт. На думку В. В. Рибалка [12], у старшому шкільному віці творчий розвиток особистості встає на професійну основу й набуває надзвичайної інтенсивності. В умовах помітної визначеності життєвої мети важливим фактором розвитку особистості стає самостійна творча діяльність у конкретному напрямку на високому рівні майстерності. Неабияка вимогливість юного обдарування до себе, усвідомлення ним безмежності можливостей самовдосконалення стає причиною того, що поглиблений творчий розвиток може затягуватися у часі, переходити в стадію, так би мовити, тривалого творчого стажування, який може охоплювати періоди юності й молодості. Вище представлені факти обумовлюють виділення ще однієї важливої складової процесу соціалізації старшокласників - це розвиток образного $i$ вербального творчого мислення. Провідні напрями соціалізації відповідають ключовим сферам життєдіяльності кожної людини: поведінковій, емоційно-чуттєвій, пізнавальній, моральноетичній, побутовій, міжособистісній [12]. Таким чином, старшокласники, соціалізуючись, навчаються, як себе поводити, емоційно реагувати на різні ситуації, проявляти і переживати почуття, яким чином пізнавати оточуючий світ, яких моральних, орієнтирів дотримуватися, як організувати свій побут і ефективно будувати міжособистісне спілкування та діяльність [43; 247].

За теоретичним аналізом зарубіжних і вітчизняних вчених, у старшому шкільному віці головною лінією стає соціальний розвиток і творче самовдосконалення. Соціалізація старшокласників опосередкована віковими та психологічними особливостями ранньої юності, до яких, у першу чергу, відноситься повне структурування самосвідомості (Г. С. Абрамова, Г. М. Андреєва, Л. І. Божович, Д. Б. Ельконін, Е. Еріксон, Дж. Роджерс, О. В. Скрипченко), перехід на якісно новий рівень моральної свідомості (М. Й. Боришевський); розвиток інтелекту (Ж. П'яже, О. О. Реан), розвиток творчого мислення (В. М. Дружинін, Г. С. Костюк, М. С. Лейтес, В. О. Моляко, О. Д. Музика, І. П. Павлов, М. Парлоф, В. В. Рибалко, В. А. Роменець), формування характеру (О. І. Лічко), цілепокладання (Ю. М. Швалб), самооцінка (І. Ю. Кулагіна), 
соціальний статус (С. Д. Максименко, Дж. Морено, Т. Д. Щербан), становлення особистісного самовизначення (Т. Д. Драгунова, Д. Б. Ельконін, Л. С. Славіна). У процесі соціалізації юнак переходить 3 позиції реципієнта соціальних впливів до позиції активного суб'єкта, тобто активно відтворює соціальні норми та відношення за рахунок діяльності і творчої реалізації. [1-14].

Висновки та перспективи подальших досліджень. Існування вікової періодизації розвитку творчого мислення передбачає інтенсивний розвиток творчого потенціалу саме в юнацькому віці (Н. I. Гайдамашко, В. М. Дружинін, В. О. Моляко, С. К. Шандарук) [11]， тому， як зазначає О. А. Смалько, цей вік - остання сходинка дітей у доросле життя, яке з року в рік посилює вимоги до рівня розвитку мислення особистостей, до здатності творчих звершень, до конструювання чогось нового, цікавого, незвичайного. I чим вищий рівень розвитку суспільства, його культури та технологій, тим більше загострюються проблеми, пов'язані з вимогами до рівня творчості його громадян, тим вище цінується здатність творчо мислити та створювати інтелектуальні і матеріальні цінності, соціально прийнятні і визнані. Отже, успішна творча соціальна ситуація розвитку юнаків залежить від основних складових соціалізації: соціальне визнання, соиіальний статус, соціальна адаптація, фрустрачія, набуті характеристики; і розвитку складових образного і вербального творчого мислення.

Теоретично обгрунтовано, що зміст і структура творчої соиіалізаиї̈ особистості проявляються у: соціальній творчості, соціальній креативності як вищих формах соціальної активності особистості або суспільства; творчій адаптації як процесі змін, перебудові соціальних ситуацій на основі незахисних адаптивних механізмів. Тому творча соціалізація $є$ найвищим щаблем соціалізації людини в середовищі. Встановлено, що творча соиіалізаиія - це процес стійкої, загальної адаптованості на підставі активізації незахисних адаптаційних механізмів психіки, що призводить до систематизації, конструювання, інтегрування особистістю образу світу і проявляється у майстерності, винахідливості, творенні нових, корисних продуктів діяльності, а також у соціальній лабільності, в якій здійснюється ії творче самовизначення [12]. Перспективами подальших досліджень $\epsilon$ вивчення умов розвитку творчої соціалізації на різних вікових етапах.

\section{Список використаних джерел}

1. Алдер Г. CQ, или Мускулы творческого интеллекта / Г. Алдер. - пер. с англ. С. Потапенко. - М. : ФАИР-ПРЕСС, 2004. - 496 с.

2. Дружинин В. Н. Психология общих способностей / В. Н. Дружинін. - СПб. : Питер, 1999. $-368 \mathrm{c}$.

3. Ермолаева-Томина Л. Б. Креативность как реализация потенциальных возможностей человека / Л. Б. Ермолаева-Томина // Современные технологии обучения художественнографическим дисциплинам : сборник. - М. : Прометей, 2001.

4. Кучерявий I. Т. Творчість - основа розвитку потенційних джерел особистості : навч. посіб. / І. Т. Кучерявий, О. І. Клепіков. - Київ : Вища шк., 2000. - 288 с.

5. Коломийченко Л. В. Концепция и программа социального развития детей дошкольного возраста / Л. В. Коломийченко. - Пермь, 2002. - 115 с.

6. Моляко В. А. Процесс творческой деятельности / В. О. Моляко // Материалы Вторых международных Костюковских чтений. - Киев, 1994. - С. 81-84.

7. Музика О. Л. Цінності обдарованої особистості / О. Л. Музика // Обдарована дитина. 1998. - № 4. - С. 6-10.

8. Полякова Г. Шляхи в творчість / Г. Полякова // Психолог. - 2003. - № 39 (87). - С. 1-4.

9. Реан А. А. Психология личности. Социализация, поведение, общение / А. А. Реан. - СПб. : «Прайм - ЕВРОЗНАК», 2004. - 416 с. - (Проект «Мэтры психологии»).

10. Роменець В. А. Психологія творчості : навч. посіб. / В. А. Роменець. - 2-ге вид., допов. Київ : Либідь, 2001. - 288 с.

11. Смолінчук Л. С. Творчість і життєвий шлях особистості [Електронний ресурс] / Л. С. Смолінчук. -Режим доступу : http//www.newacropolis.org.ua/ua/ study/conference/?thesis=4140.

12. Сторож О. В. Психологічні особливості творчої соціалізації старшокласників : дис.... канд.. психол. наук : 19.00 .01 / О. В. Сторож. - Київ, 2011. - 358 с.

13. Туріна О. А. Культуротворчі чинники творчої соціалізації особи / О. А. Туріна // Вісник Книжкової палати. - 2011. - № 1. - С. 35-40.

14. Ямницький В. М. Психологія життєтворчої активності особистості : монографія / В. М. Ямницький. - Одеса : СВД Черкасов М. П. ; Рівне : РДГУ, 2004. - 360 с. 


\section{References}

1. Alder G. CQ, ili Muskuly tvorcheskogo intellekta / G. Alder. - per. s angl. S. Potapenko. - M. : FAIR-PRESS, 2004. - $496 \mathrm{~s}$.

2. Druzhynyn V. N. Psykholohyia obshchykh sposobnostei / V. N. Druzhynin. - SPb. : Pyter, 1999. $-368 \mathrm{~s}$.

3. Ermolaeva-Tomyna L. B. Kreatyvnost kak realyzatsyia potentsyalnыkh vozmozhnostei cheloveka / L. B. Ermolaeva-Tomyna // Sovremennыe tekhnolohyy obuchenyia khudozhestvenno-hrafycheskym dystsyplynam : sbornyk. - M. : Prometei, 2001.

4. Kucheriavyi I. T. Tvorchist - osnova rozvytku potentsiinykh dzherel osobystosti : navch. posib. / I. T. Kucheriavyi, O. I. Klepikov. - Kyev : Vyshcha shk., 2000. - 288 s.

5. Kolomyichenko L. V. Kontseptsyia y prohramma sotsyalnoho razvytyia detei doshkolnoho vozrasta / L. V. Kolomyichenko. - Perm, 2002. - 115 s.

6. Moliako V. A. Protsess tvorcheskoi deiatelnosty / V. O. Moliako // Materyalы Vtorыkh mezhdunarodnыkh Kostiukovskykh chtenyi. - Kyev, 1994. - S. 81-84.

7. Muzyka O. L. Tsinnosti obdarovanoi osobystosti / O. L. Muzyka // Obdarovana dytyna. - 1998. № 4. - S. 6-10.

8. Poliakova H. Shliakhy v tvorchist / H. Poliakova // Psykholoh. - 2003. - № 39 (87). - S. 1-4.

9. Rean A. A. Psykholohyia lychnosty. Sotsyalyzatsyia, povedenye, obshchenye / A. A. Rean. SPb. : «Praim - EVROZNAK», 2004. - 416 s. - (Proekt «Mэtrы psykholohyy»).

10. Romenets V. A. Psykholohiia tvorchosti : navch. posib. / V. A. Romenets. - 2-he vyd., dopov. Kyyiv : Lybid, 2001. - 288 s.

11. Smolinchuk L. S. Tvorchist i zhyttievyi shliakh osobystosti [Elektronnyi resurs] / L. S. Smolinchuk. - Rezhym dostupu : http://www.newacropolis.org.ua/ua/ study/sonference/?thesis=4140.

12. Storozh O. V. Psykholohichni osoblyvosti tvorchoi sotsializatsii starshoklasnykiv : dys.... kand.. psykhol. nauk : 19.00.01 / O. V. Storozh. - Kyyiv, 2011. - 358 s.

13. Turina O. A. Kulturotvorchi chynnyky tvorchoi sotsializatsii osoby / O. A.Turina // Visnyk Knyzhkovoi palaty. - 2011. - № 1. - S. 35-40.

14. Iamnytskyi V. M. Psykholohiia zhyttietvorchoi aktyvnosti osobystosti : monohrafiia / V. M. Yamnytskyi. - Odesa : SVD Cherkasov M. P. ; Rivne : RDHU, 2004. - 360 s.

\section{O. V. Storozh AGE REGULATIONS OF THE DEVELOPMENT OF YOUTH CREATIVE SOCIALIZATION.}

The article is dedicated to the theoretical analysis of age regulation of the development of creative socialization. Analysis of the scientific literature which explaines the meaning of the concept "creative socialization" was carried out. Main components of creative socialization were substantiated: social and psychological adaptation, frustration, social status, social recognition, acquired characteristics, figurative and verbal thinking, theme originality. The gist of youth creative socialization was discovered. It was brought out that the content and structure of youth creative socialization are based on the connection between socialization components and creative thinking. They appear in social creativity as a higher form of social activity of the personality or society; creative adaptation as the process of changes; the rennovation of social situations based on non-protective adaptive mechanism; creative socialization as the highest level of human socialization in the enviroment. It was justified that youth creative socialization is the process of constant total adaptation on the basis of activation of non-protective adaptive mechanism of phycho which leads to systematization, designing, youth's integrating of world image and is shown in proficiency, inventiveness, creation of new, useful action produces, also in social lability in which their creative selfrealization is made.

Key words: socialization, social adaptation, social status, creative socialization, creative selfrealization, accommodation, social creativity, creative giftedness, creative adaptation, frustration, figurative and verbal creative thinking, theme originality, creative socialization components. 